\title{
BUFFER PROPERTIES OF BENTONITE BARRIER SYSTEMS FOR RADIOACTIVE WASTE ISOLATION IN GEOLOGICAL REPOSITORY IN THE NIZHNEKANSKIY MASSIF
}

\author{
Krupskaya V. V. ${ }^{1,2}$, Zakusin S. V. ${ }^{1,3}$, Lekhov V. A. ${ }^{3}$, Dorzhieva O. V. ${ }^{1}$, Belousov P. E. ${ }^{1}$, Tyupina E. A. ${ }^{4}$ \\ ${ }^{1}$ Institute of Geology of Ore Deposits, Petrography, Mineralogy, and Geochemistry, Russian Academy of Sciences, \\ Moscow, Russia \\ ${ }^{2}$ Nuclear Safety Institute of the Russian Academy of Sciences, Moscow, Russia \\ ${ }^{3}$ Moscow State University, Geological Faculty, Moscow, Russia \\ ${ }^{4}$ D. Mendeleev University of Chemical Technology of Russia, Moscow, Russia
}

Article received on January 14, 2020

\begin{abstract}
The paper discusses the main properties of bentonite clays being considered as a component of safety barriers for radioactive waste isolation in geological repositories. It focuses on experimental and analytical studies providing basic information needed to select the most suitable material for the experiments that are to be carried out in the underground research laboratory and for the construction of the geological repository. The paper summarizes the required full-scale and supporting laboratory experiments that are to be implemented in the underground research laboratory being constructed in the Nizhnekanskiy massif (Krasnoyarsk Region). The proposed experiments were based on the requirements and basic properties of bentonite being considered as the engineered barrier for radioactive waste disposal. As a result of laboratory and full-scale experiments the information required to assess the repository's evolution following its closure will be obtained.
\end{abstract}

Keywords: bentonite, radioactive waste, engineered barriers, geological repository, bentonite properties, laboratory and full-scale experiments, Nizhnekanskiy massif.

To ensure the safety of high-level waste (HLW) and spent nuclear fuel (SNF) final isolation the option of its disposal in deep geological formations (clays, salts, crystalline rocks) has been considered by the majority of countries around the world. Passive multi-barrier systems designed to ensure the isolation of waste from the biosphere are viewed as an important component of the deep disposal facilities for RW (DDF RW). Such systems commonly involve a natural geological barrier represented by the geological environment and a complex of artificial barriers (engineered safety barriers, EBS). Buffer material used to seal RW packages and underground excavation is considered as an EBS element. The overwhelming majority of currently developed concepts propose the use of bentonite or bentonite-based mixtures with other materials [1-4]. Tunnel backfill (bentonite/sand and bentonite/crushed rock mixtures are considered in European DDF RW concepts [5]) the application of which is regulated by less stringent requirements is not considered in this paper. Buffer materials made of compacted (compressed) bentonite can be used in the repository as pellets similar to Swiss designs or blocks of various shapes, as considered in the disposal designs in Sweden, Finland, etc. [1, 6, 7]. 
The main requirements to the buffer material during HLW disposal are as follows: low permeability; self-sealing capacity; high sorption capacity considering a number of radionuclides; long-term preservation of the required properties [1, 7-9]. Among natural materials, only bentonite and bentonite-like clays are characterized by a full set of required properties. Bentonite was selected as a buffer material under national HLW disposal programs in Sweden and Finland considering crystalline rocks (granite massifs) as a bedrock formation.

Containment of radionuclides within the DDF RW and retardation of their release into the environment is seen as the main protective function of EBS materials. Protective functions can be identified based on the available knowledge on EBS material properties and their evolution in the long term. Studies performed in underground research laboratories (URL) under conditions being as far as possible similar to the actual disposal ones can provide most reliable information on EBS material properties. This paper considers the main properties of the bentonite buffer as a part of the EBS system during HLW disposal and presents the envisaged full-scale and laboratory experiments.

\section{Containment properties of bentonites and the criteria defining its application as an EBS component}

RW disposal suggests a new quality application of bentonite and bentonite-based products considering it already as a "tailored construction material", thus, the evaluation of its characteristics requires the development of new approaches and standards. Research teams from different countries are working on their own original concepts and standards, which, despite some significant similarities, nevertheless, are having their individual characteristics which is explained by a number of economic, geological, geographical, engineering and other features.

Smectites, mainly montmorillonites (over 60$70 \%$ ), are considered as the main rock constituent of bentonite clays. Quartz, feldspars, calcite, rarely pyrite and organic matters, as well as other clay minerals - kaolinite, illite, mixed-layer minerals, less often chlorite and vermiculite are found in it as impurities.

Isomorphic substitution of cations within octahedral and tetrahedral meshes of clay minerals results in a negative charge of the layer, which is compensated by interlayer cations and provides high sorption and waterproofing capacity of bentonite clays (Figure 1). Predominance of isomorphic substitutions in octahedral meshes and a sufficient layer charge ensures most favorable sorption and colloidal capacities of soils and rocks with a high montmorillonite content.

Based on the exchange cation composition in the montmorillonite interlayer complex, bentonite clays are subdivided into alkaline (sodium) and alkaline-earth (calcium-magnesium) types. Alkaline bentonites are believed to have most favorable properties and are commonly applied in a few industrial sectors compared to alkaline-earth bentonites, which is explained by a higher hydration potential of alkali metal ions, primarily sodium. Thus, the free swelling capacity of Na-montmorillonites is much higher compared to Ca-montmorillonites. However, studies of compacted bentonites have shown that this effect is observed only at low

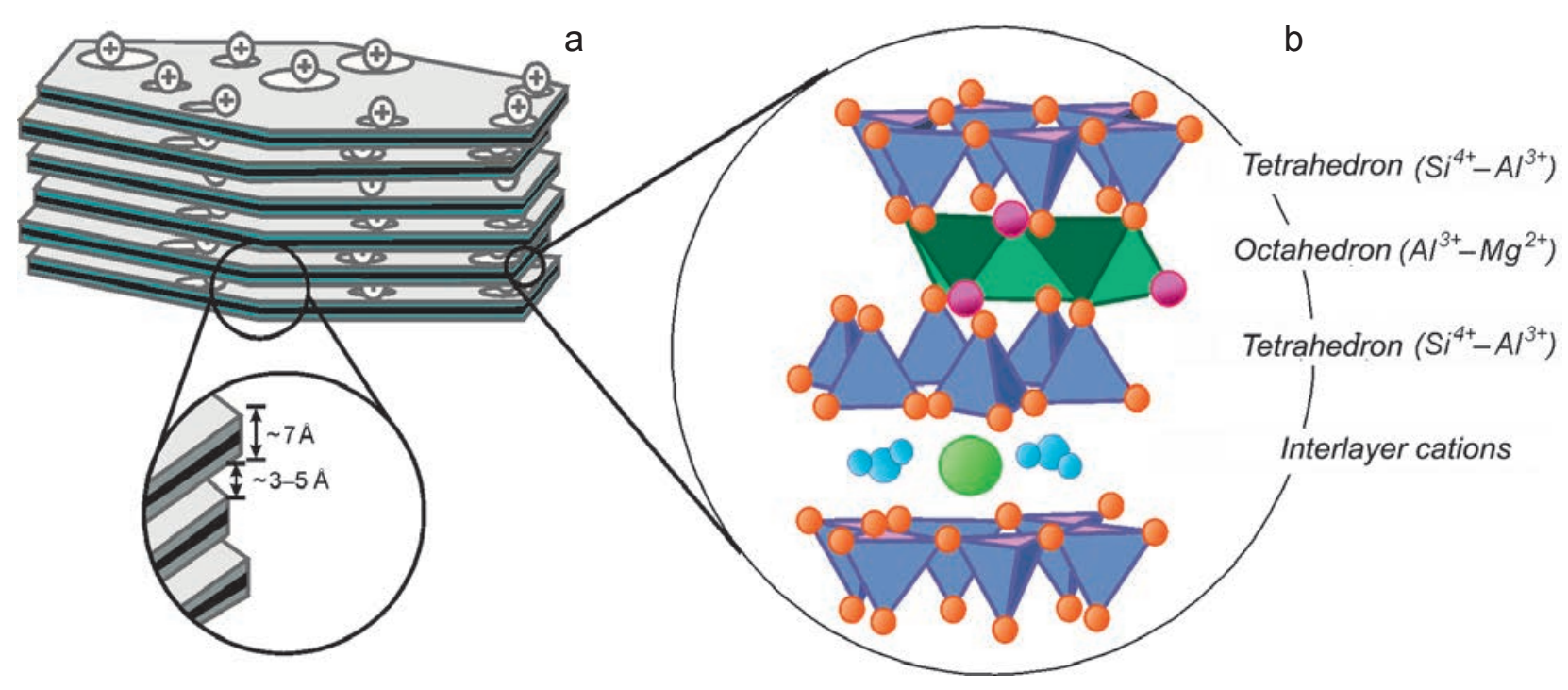

Figure 1. Schematic presentation of a montmorillonite particle with negative charge located at the layer surface (a) and the structure of a smectite layer (b) 
densities of the compacted bentonite (below 1.3$\left.1.5 \mathrm{~g} / \mathrm{cm}^{3}\right)$ being completely absent at high densities (more than $1.7 \mathrm{~g} / \mathrm{cm}^{3}$ ) [7,10].

Presence of montmorillonite in clays is considered as an essential factor enabling their use as a buffer material (Table 1). Presumably, most of the minor minerals contained in bentonites (quartz, feldspars, other clay minerals, etc.) will not produce any negative impact on the barrier material properties. However, studies have shown that the presence of gypsum, anhydrite, pyrite and organic matters can contribute to metal HLW container corrosion, favor the development of a potentially aggressive environment for the concrete and promote gas generation $[11,12]$. Based on longterm experiments, the scientific community adopted some criteria on the mineral composition of bentonite clays being considered suitable for EBS construction. However, these criteria are not universal and each criterion should be tailored to the conditions available at a particular repository site [7].

Table 1. Restrictions on the contents of some components according to the requirements of the Swedish KBS-3 disposal concept (SKB) [13]

\begin{tabular}{|c|c|}
\hline Design content, \% wt & Acceptable content, \% wt \\
\hline \multicolumn{2}{|c|}{ montmorillonite } \\
\hline $80-85$ & $75-90$ \\
\hline \multicolumn{2}{|c|}{ sulfide } \\
\hline limited & $<0.5$ \\
\hline \multicolumn{2}{|c|}{ sulfur, including sulfide sulfur } \\
\hline limited & $<1$ \\
\hline \multicolumn{2}{|c|}{ organic carbon } \\
\hline limited & $<1$ \\
\hline
\end{tabular}

Thus, Swedish repository concept considers bentonite with a montmorillonite content of $80-85 \%$ (with an acceptable variation in the range of 75$90 \%$ ) as a material suitable for buffer fabrication. The content of organic carbon should be less than $1 \%$, of sulfides - not more than $0.5 \%$, whereas, the total sulfur content should be limited to $1 \%$ of the total mass [13]. Bentonite is used to manufacture buffer blocks and disks with a density ranging from 1.65 to $2.05 \mathrm{~g} / \mathrm{cm}^{3}$ providing a swelling capacity of at least $2 \mathrm{MPa}$ and a water conductivity coefficient of around $10^{-11}-10^{-12} \mathrm{~m} / \mathrm{s}$ (Table 1).

Finnish concept [14] considers both alkaline and alkaline-earth types of bentonites (Table 2) with bentonite from the Wyoming deposit (MX-80) involved in a rather large number of the experiments and oftentimes considered as a reference material.
Table 2. Acceptance criteria for the bentonite clays used as an EBS component under the disposal concept adopted in Finland [14]

\begin{tabular}{|c|c|}
\hline Na-bentonite & Ca-bentonite \\
\hline \multicolumn{2}{|c|}{ Water content (moisture content), \% } \\
\hline$\leqslant 13$ & $\leqslant 13$ \\
\hline \multicolumn{2}{|c|}{ Swelling capacity, $\mathrm{ml} / 2 \mathrm{~g}$} \\
\hline$\geqslant 20$ & $\geqslant 15$ \\
\hline \multicolumn{2}{|c|}{ Smectite content, \% } \\
\hline$\geqslant 75$ & $\geqslant 75$ \\
\hline \multicolumn{2}{|c|}{ Total moisture capacity, \% } \\
\hline$\geqslant 250$ & $\geqslant 80$ \\
\hline \multicolumn{2}{|c|}{ Cation-exchange capacity (CEC), mEq/100 g } \\
\hline$\geqslant 70$ & $\geqslant 60$ \\
\hline \multicolumn{2}{|c|}{$\begin{array}{l}\text { Water conductivity coefficient (assuming a matrix density of the } \\
\left.\text { rock of } 1.75 \mathrm{~g} / \mathrm{cm}^{3}\right), \mathrm{m} / \mathrm{s}\end{array}$} \\
\hline$\leqslant 10^{-12}$ & $\leqslant 10^{-12}$ \\
\hline \multicolumn{2}{|c|}{ Swelling pressure, $\mathrm{MPa}$} \\
\hline $1-10$ & $1-10$ \\
\hline \multicolumn{2}{|c|}{ Thermal conductivity coefficient, $\mathrm{W} / \mathrm{m} \cdot \mathrm{K}$} \\
\hline 1.0 & 1.0 \\
\hline
\end{tabular}

Deposits of rather high-quality bentonites are available in the territory of the Russian Federation and the near abroad [15-17]. Table 3 presents the main characteristics of bentonites from large industrial deposits of the Russian Federation and its neighboring countries, the raw materials from which are available on the Russian market and which can be potentially used under the Russian disposal concept

The cation exchange capacity (CEC) indicators were calculated using two different methods: the adsorption of methylene blue dye (MB) being widely used in Russian practice and the adsorption of $\mathrm{Cu}$ (trien) complex, which is currently recognized by the scientific community as the most correct one in terms of evaluating bentonite CEC and, in particular, in case of alkaline-earth differences $[18,19]$.

\section{Compaction of bentonites and their physical and mechanical properties}

A number of issues can be addressed through the application of materials manufactured from bentonite clays and having an increased density, for example, it can promote the formation of necessary physical and mechanical properties of EBS materials [7], help to control swelling pressure and permeability. Moreover, the use of compacted materials ensures both the homogeneity of the constructed barriers and facilitates the transportation of their 
Table 3. The main composition and property indicators for natural bentonite clays from the industrial deposits of the Russian Federation and its neighboring countries

\begin{tabular}{|c|c|c|c|}
\hline $\begin{array}{l}10 \text { th Khutor, } \\
\text { Republic of } \\
\text { Khakassia }\end{array}$ & \begin{tabular}{|c|} 
Zyryansk \\
deposit, Kurgan \\
District, Russia
\end{tabular} & $\begin{array}{c}\text { Tagansk (Dinosaur) } \\
\text { deposit, Republic } \\
\text { of Kazakhstan }\end{array}$ & $\begin{array}{c}\text { Dash-Salahlinsk } \\
\text { deposit, } \\
\text { Azerbaijan }\end{array}$ \\
\hline \multicolumn{4}{|c|}{ Smectite (montmorillonite) content, wt. \% } \\
\hline 73 & 74 & 73 & 74 \\
\hline \multicolumn{4}{|c|}{ Total charge of the montmorillonite layer } \\
\hline 0.44 & 0.55 & 0.55 & 0.50 \\
\hline \multicolumn{4}{|c|}{ Tetrahedral charge, \% } \\
\hline 3.2 & 26.8 & 0.5 & 0.8 \\
\hline \multicolumn{4}{|c|}{ Prevalence of cis-/ trance- vacant octahedra } \\
\hline cis- & cis-/trans- & trans- & cis- \\
\hline \multicolumn{4}{|c|}{ Cation exchange capacity by the Trien method ${ }^{*}, \mathrm{mEq} / 100 \mathrm{~g}$} \\
\hline 80.2 & 78.3 & 100.7 & 94.1 \\
\hline \multicolumn{4}{|c|}{ Cation exchange capacity by MB method*, mEq/100 g } \\
\hline 36.8 & 27.3 & 81.6 & 80.2 \\
\hline \multicolumn{4}{|c|}{ Free swelling capacity, $\mathrm{ml} / 2 \mathrm{~g}$} \\
\hline 10 & 18 & 19 & Not measured \\
\hline \multicolumn{4}{|c|}{$\mathrm{Fe}_{2} \mathrm{O}_{3}$ content, wt. \% } \\
\hline 4.1 & 8 & 6.7 & 5.8 \\
\hline \multicolumn{4}{|c|}{ Organic carbon (Corg) content, wt. \% } \\
\hline$<0.05$ & $<0.05$ & $<0.05$ & Not measured \\
\hline \multicolumn{4}{|c|}{ Sulfur content, wt. \% } \\
\hline 0.11 & 0.07 & 0.04 & $<0.1$ \\
\hline
\end{tabular}

${ }^{*}$ methylene blue dye adsorption method (MB)

** method of $\mathrm{Cu}$ (rien)complex adsorption

elements to the intended locations [1]. It is important to understand which parameters should be monitored during the selection of an appropriate compaction mode and which property indicators should be assumed as a quality assessment criterion for the resulting material.

Desired matrix density, humidity and particle size distribution (particle size of the bentonite material) are viewed as the key parameters during the selection of the compaction mode. Thus, swelling and permeability parameters of the barrier material will depend on the matrix density, whereas, the strength of the compacted material and the force applied to achieve the desired density will depend on the moisture content and the particle size distribution in the raw material. It is important that the swelling pressure and the permeability would depend to a smallest extent possible on the matrix density: comparison of various bentonite property indicators reveals that the bentonites whose permeability and swelling pressure is least dependent on the matrix density are considered as more suitable for the fabrication of HLW containment ESB [7].

Pressing is considered as the most effective compaction method for bentonites. Moreover, the required parameters cannot be achieved through the application of tamping considered as a standard compaction method [20], which is explained by the fact that sufficient exposure time and the efforts required to achieve a uniform distribution of the pore fluid and to provide the development of transitional (point-like) and coagulation contacts between particles at a low humidity cannot be attained in case of an impulse (shock) load impact.

Uniaxial compressive strength can be considered as a primary criterion for the quality assessment of compacted bentonite. As a first approximation, this parameter can help to assess how well the material can maintain its integrity during transportation, backfilling and repository operation. Studies have shown that the highest strength of compacted bentonite from the Wyoming deposit can be achieved through the application of industrial grinding method with its grinding to an average size of 0.25-1 $\mathrm{mm}$ [21], while an optimal fraction size of less than $0.1 \mathrm{~mm}$ is considered for bentonites from the 10th Khutor deposit which was demonstrated in a preliminary study.

The optimal moisture content of compaction for the bentonites from the Wyoming deposit was estimated to be equal to $17 \%$ [21], whereas the studies of the bentonites from the 10th Khutor deposit showed that the optimal moisture content could amount to some $20 \%$.

\section{Swelling}

Swelling of bentonite material interacting with water is considered as a main property ensuring the containment function by filling the voids (selfsealing) inside the installed barrier resulting in a homogeneous medium even if elements of a different shape are used (blocks, pellets, granules, etc.) (Figure 2).

Swelling pressure of compacted bentonite basically depends on the matrix density and bentonite characteristics themselves (particle size distribution, smectite content, layer charge and distribution, chemical composition of exchange cations). Permeability (water conductivity coefficient) quite strongly depends on the swelling pressure [7].

Micromorphological characteristics of compacted bentonites before and after wetting were studied revealing a number of changes in their microstructure. The microstructure of natural compacted clays before wetting involves microaggregates of elongated leaf-shaped smectite clay particles. These are 

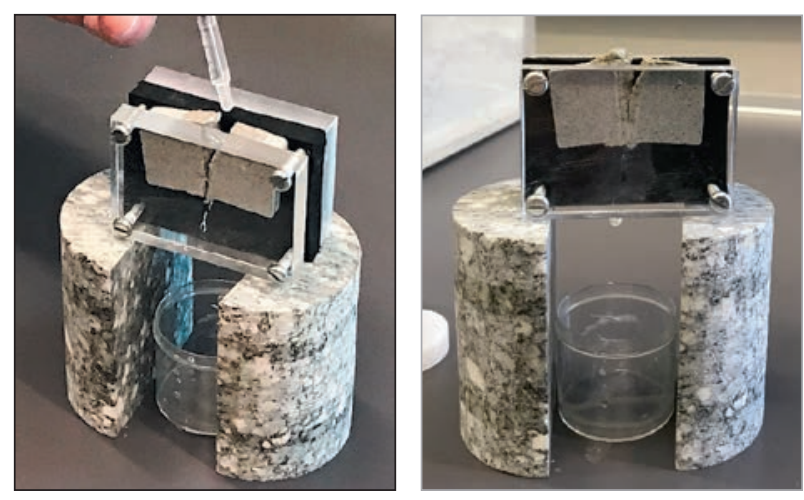

Figure 2. Demonstration of the compacted bentonite selfsealing capacity upon its interaction with water. Photos were taken with a 10-minute interval
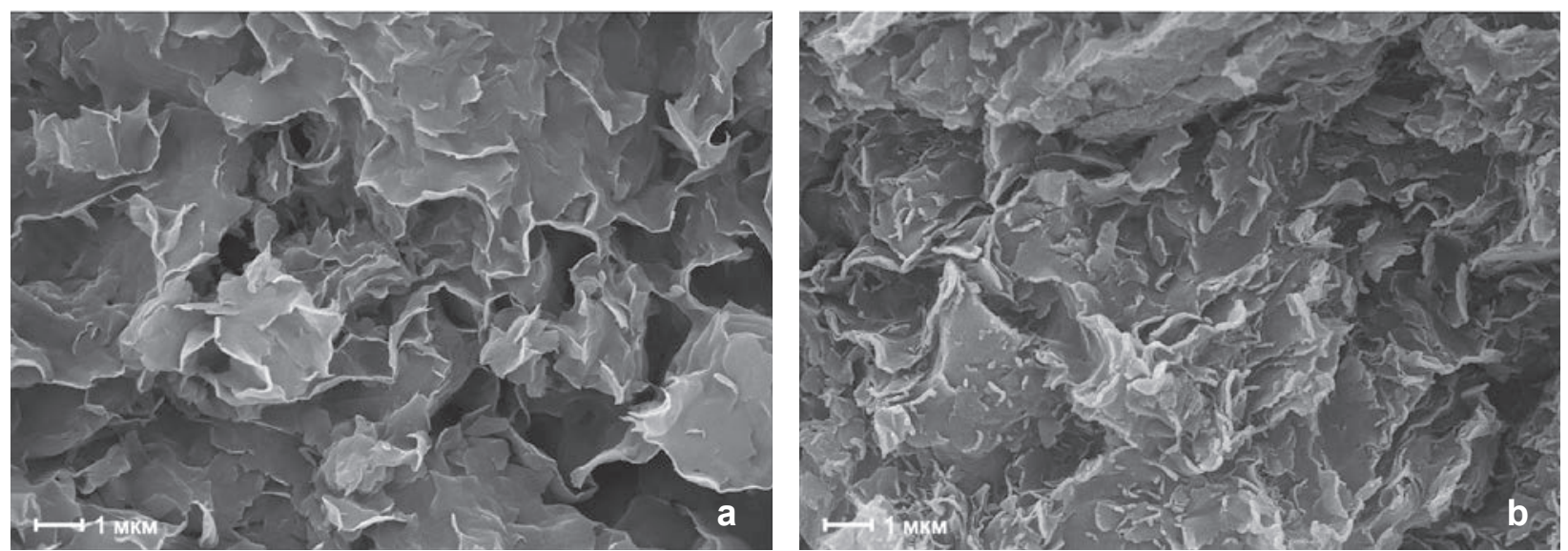

aggregated forming larger structures (Figure 3a) ranging from 1 to 10 microns in their size with a thickness of $0.5-3$ microns incorporating numerous small interparticle endo-microaggregate and inter-microaggregate pores. After wetting, the size of microaggregates and the number of pores tend to decrease, which is explained by clay particle hydration upon sample saturation with water. Smectite particle and aggregate swelling cause a decrease in their average size and in their orientation degree with some pores being sealed resulting in a more homogenous microstructure (Figure 3b) [22, 23].

Within the macro-volume, the observed changes in the microstructure caused by swelling result in a

Figure 3. Decreased porosity in compacted bentonite clays (10th Khutor) upon watering: a - moisture content of $11 \%$, $b-$ moisture content of $45 \%$

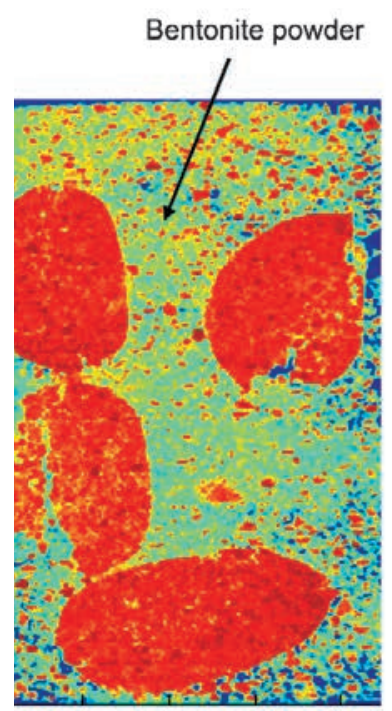

Freshly filled mixture

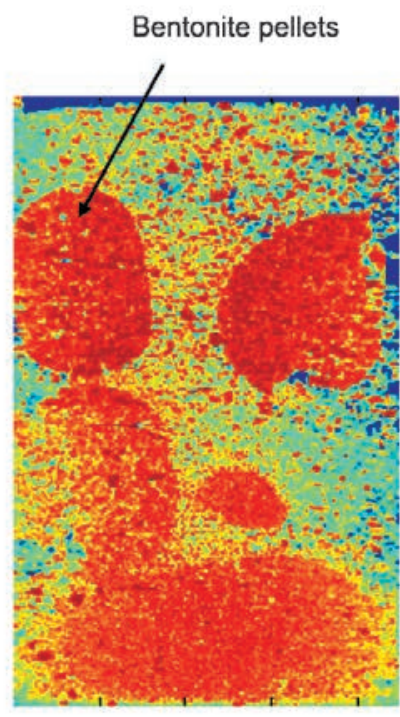

Mixture after 0.5 months 
rather rapid averaging of the inhomogeneous material, self-sealing of large pores at the boundaries of areas characterized by different densities and the development of an almost pore-free homogeneous system. Study [24] showed that 2.5 monthslong saturation of compacted bentonite pallets and powder results in a high-level homogenization of the barrier due to material swelling, which, in turn, can already provide the required containment capacity (Figure 4).

Swelling pressure depends exponentially on the density, which should be considered when simulating the stress-strain state of the DDF RW bedrocks [25-27]. It should be borne in mind that changes in the chemical composition of the pore water, prolonged heat exposure in the vicinity of HLW containers (near field) and potential transformations of bentonite composition and structure resulting from metal container corrosion can affect swelling pressure indicators, and hence the waterproofing properties of the barrier.

Swelling pressure is viewed as a most important bentonite buffer property indicator which should be high enough to provide necessary self-sealing capacity during closure, but should not exceed critical values, so as not to produce a destructive load on the container and the walls of the excavation. According to various sources, the swelling pressure should fall within a range of $0.2-15 \mathrm{MPa}$.

\section{Water permeability}

Low water permeability is seen as an essential property of bentonite clays providing containment, which can be basically provided through the use of compacted high-density bentonite materials proposed under the vast majority of modern RW disposal concepts.

The theory of filtration occurring in sediments with low-permeability, including bentonite-based engineered safety barriers, implies the presence of an advective water flow only if the initial pressure gradient is available.

Microstructure of the pore space developed following compacted bentonite sample hydration was studied. It was found that the available active pore space, where the filtration can occur, will be minimal or absent [28]. The size of the developed pores depends on the swelling pressure, which, in turn, depends on the structural features of montmorillonite and the solution composition.

To ensure the long-term safety of RW disposal the buffer water conductivity coefficient should fall within the range between $10^{-11}-10^{-12} \mathrm{~m} / \mathrm{s}$ depending on the repository concept and the waste type.

\section{Thermal conductivity}

The heat generated by HLW or SNF containers due to the radioactive decay should be dissipated to limit the maximum temperature in the nearfield ensuring safe operation of the repository. Temperature in the bentonite buffer will reach its peak during the first $50-100$ years after DDF RW closure, when the residual heat release coming from the waste is still high and the bentonite is not completely saturated and swollen [27]. Studies performed under laboratory conditions and the full-scale experiments that can be exemplified by the FEBEX (Full Scale Engineered Barriers Experiment) project showed that the thermal conductivity of bentonite decreases significantly at a moisture content level below $50 \%$ and remains almost constant at a moisture content level ranging from 50 to $100 \%$ [29-31]. Thus, it's clear that at a moisture content of at least $50 \%$, bentonite will be characterized by most favorable properties that can evolve under repository conditions when the temperature in the vicinity of a waste container drops below $100^{\circ} \mathrm{C}$. However, the lithostatic pressure available at the depth has not been accounted for in the above studies, therefore, the criteria for the temperature level may be revised.

\section{Radiation resistance}

Most likely, the bentonite buffer will not be exposed to $\alpha$ - and $\beta$-radiation until radionuclide release beyond the confining container occurs. Exposure of $\gamma$-radiation emitted by the waste can cause structure changes in montmorillonite potentially leading to a decrease in its content in bentonite and, consequently, to a decrease in its swelling capacity and its ability to maintain low water permeability. Studies have shown that montmorillonite amorphization occurs when the absorbed dose reaches 30 GGy [33]. At the same time, under deep repository conditions, bentonite will be exposed to a total radiation dose that is assumed to produce no noticeable changes on montmorillonite content and its properties [34].

\section{Biological resistance}

Bentonite buffer and host rocks, as any other natural material, feature some amounts of sulfatereducing bacteria producing sulfides. Their number depends on the type of bacteria and nutrient content in the groundwater. Degradation of EBS structure may trigger nutrient inflow, for example, with cement additives (such as superplasticizers), organic components from rock pore water and other term sources potentially causing increased bacterial growth. 
Microbiological activity can be limited by reducing nutrient diffusion and increasing the swelling pressure, which is achieved by increasing the bentonite material density. A more detailed discussion of microbiological influences and corresponding full-scale experiments is presented in [35].

\section{Bentonite transformations under repository conditions}

In addition to the identification of main bentonite buffer property indicators, knowledge on their potential transformations under the influence of various factors during their operation as part of the repository barrier materials seems to be essential. Increased temperature in the vicinity of RW packages is seen as one of these factors. Different estimates show that the bentonite buffer will be exposed to a temperature ranging from 80 to $140^{\circ} \mathrm{C}$. Full-scale experiments performed in Äspö URL (ABM project - Alternative Buffer Materials) involving a mockup iron canister with HLW simulator showed that under the influence of elevated temperatures $\left(140{ }^{\circ} \mathrm{C}\right)$, clusters of trioctahedral smectite (saponite) are developed along with a slight decrease in cation exchange capacity and swelling pressure [7]. Under the PR (Prototype Repository) experiment involving RW canisters made of copper and being exposed to a temperature of no more than $85^{\circ} \mathrm{C}$, no changes in the composition of bentonite clays at the canister boundary were recorded. Thus, the authors [7] suggested that copper can be considered a much more suitable material for waste canister fabrication.

It is a common knowledge that smectite group of minerals can undergo various transformations under the influence of several factors acting together, such as high temperature, pressure, physical and chemical interaction with the components of pore fluid. In addition to saponite formation mentioned above, montmorillonite can transform into illite, thus, causing the swelling montmorillonite transformation into non-swellable illite. Experiments $[36,37]$ show that given the expected groundwater composition in clay formations, $80 \%$ illitization of smectite layers can be expected only at a temperature of $150^{\circ} \mathrm{C}$ after 100,000 years. Moreover, this process is assumed to be even longer at
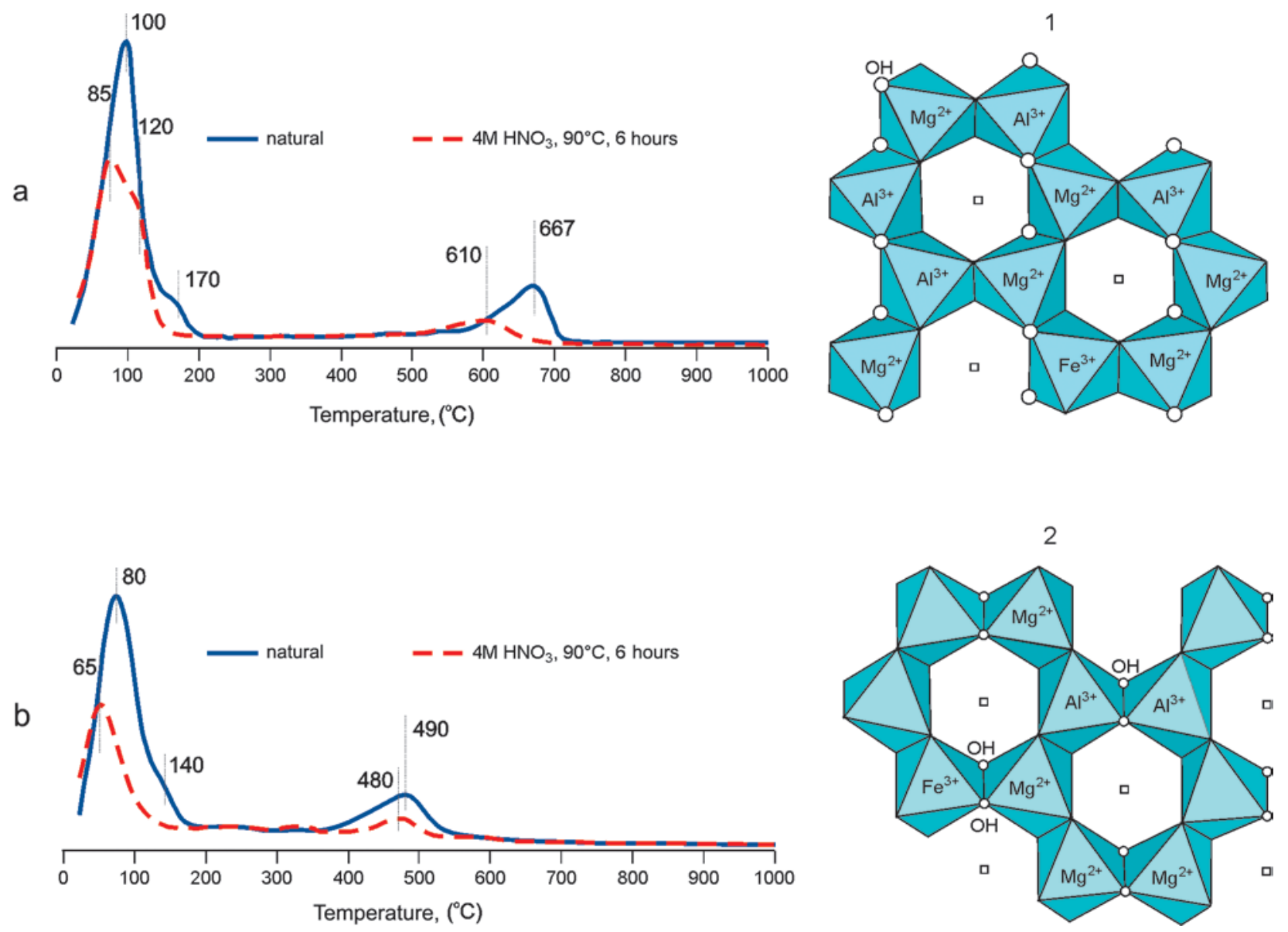

Figure 5. Results of thermogravimetric analysis for (a) cis-vacant (Trebiya deposit) and (b) trans-vacant (Tagansk deposit) montmorillonites. The insets show the orientation models of $\mathrm{OH}$-groups within the octahedral mesh according to cis- (1) and trans-motif (2) 
lower temperatures. Potassium concentration in such rocks was assumed being equal to $200 \mathrm{ppm}$. At the same time, at potassium concentration of $2,000 \mathrm{ppm}\left(150^{\circ} \mathrm{C}\right), 50 \%$ illitization of smectite layers occurs much faster (3,500 years). However, such groundwater chemistry is considered typical only for hydrothermal solutions and is not expected in crystalline bedrock along with the evolution of the geological setup. Experiments showed that conditions prompting significant montmorillonite illitization would not evolve under repository conditions.

Thus, identification of criteria being responsible for bentonite stability is believed to be as much important as the study of its key characteristics. Studies of bentonites from various deposits in Russia and the near abroad have shown that the nature of vacant position distribution within the octahedral mesh of the montmorillonite structure should be considered as a main parameter affecting the stability of smectite structure and its properties. It was shown $[38,39]$ that cis-vacant smectites are more stable than the trans-vacant ones (Figure 5).

Papers $[40,41]$ dealing with the dehydroxylation of 2:1 layered silicate, primarily mica and smectites, suggest that octahedra can be oriented in two different ways so that $\mathrm{OH}$-groups are arranged as shown in Figure $5(1,2)$. If $\mathrm{OH}$-groups are located relatively close to each other according to the trans-motive, less energy is required to break the bonds, and, thus, the dehydroxylation temperature is less than $500^{\circ} \mathrm{C}$ (falling in the range between $450-500^{\circ} \mathrm{C}$ ). If $\mathrm{OH}$-groups are located farther apart, more energy is required to break the bonds, and the dehydroxylation temperature is above $500^{\circ} \mathrm{C}$ (falling in the range between $550-650^{\circ} \mathrm{C}$ ). It can be expected that the same structural criterion appears to be significant in model transformations of bentonites under conditions similar to the repository ones and in this case can be used as a stability criterion for bentonite clays and considered in relevant models of EBS short-term and long-term evolution.

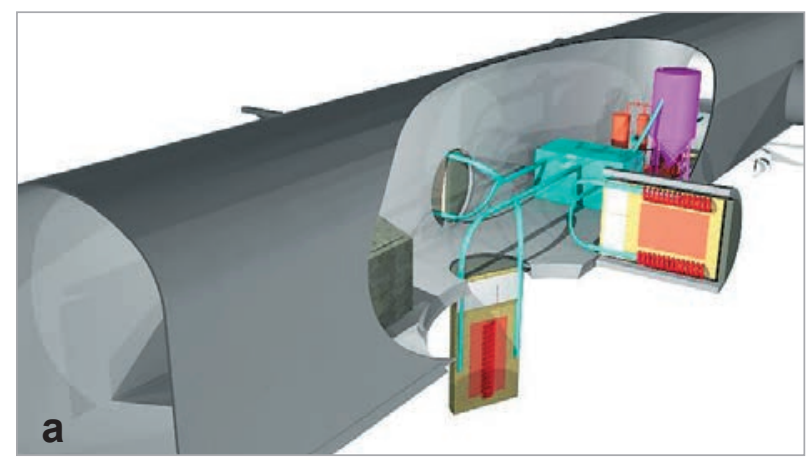

Laboratory and full-scale experiments planned in the underground research laboratory

Under current repository concept, the EBS system is viewed a multicomponent structure. It should be emphasized that to evaluate the stability of EBS material composition, structure and properties under the influence of various factors, experiments are required to be conducted under conditions being as far as possible similar to the actual disposal ones. Thus, the influence of the entire set of factors can be evaluated, since, most likely, this system will have an emergent nature.

ERLIK URL (Exploratory Rock Laboratory In Krasnoyarsk region) developed in the Nizhnekanskiy rock mass [9] is planned to hold a number of full-scale experiments to study the main processes expected in EBS materials: the effects of temperature, chemical composition of pore water, pressure, processes at EBS boundaries (corrosion and erosion of barrier materials).

A large number of experiments have already been conducted in URLs operated abroad: their findings can be used to simulate the evolution of the Russian repository. However, far from all of them can be applied directly due to the existing differences in the repository siting conditions. Discussed below is a range of laboratory, medium- and fully-scale experiments developed to study the properties of bentonite materials and relevant processes.

\section{Full-scale URL experiments}

Several series of full-scale experiments are planned to be implemented in the URL to assess the safety of the developed disposal facility designs and to study barrier material evolution, including those shown in Figure 6:

a) study of EBS material evolution under repository conditions, including relevant research of their thermal evolution, interaction of EBS materials, interaction of swelling materials constituting to the

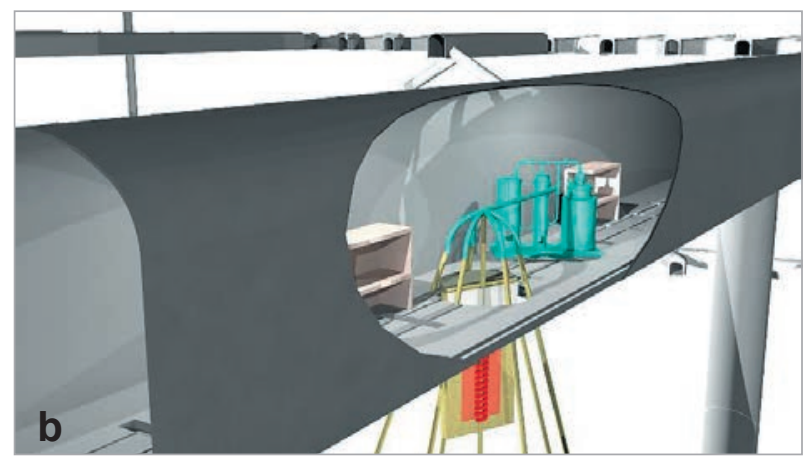

Figure 6. Design layout of installations proposed for the full-scale experiments:

$a$ - study of EBS material evolution under repository conditions, $b$ - study of gas generation and migration through EBS materials and host rocks 
tunnel backfill and concrete plugs, evolution of tunnel backfill material properties;

b) study of gas generation and migration through EBS materials and host rocks, including gas generation caused by metal container corrosion, potential loss of integrity by the bentonite buffer, gas migration.

It seems worth to take a closer look at the experiment investigating the processes occurring at the interface between compacted bentonites and metal elements of a canister. This experiment was developed to characterize bentonite buffer stability and to trace the processes of its erosion and properties evolution.

The following results are expected to be achieved during the experiment:

- to evaluate the behavior of the bentonite barrier at its interface with a metal canister under a thermal impact and in presence of model pore water (swelling, thermal stability, transformations at the interface);

- to evaluate the evolution of bentonite buffer manufactured from a material provided for under the design concept based on the main parameters (swelling pressure, thermal stability, physical, mechanical and filtration properties);

- to study the evolution of materials at the interface between bentonite - metal, bentonite backfill material between the walls of the excavation (bentonite pellets, thixotropic slip, etc.);

- to identify potentially promising alternative materials: bentonites from different deposits, clay mixtures of different composition, bentonite pallets fabricated from the material produced at different deposits, materials based on bentonite and rock mixtures;

- to evaluate EBS material corrosion rates - metal canister, bentonite, concrete, thixotropic slip, alternative buffer materials under repository conditions;

- to identify some particular aspects of processes occurring at the interfaces between various EBS materials.

The experiments involve the use of a mockup installation instead of a real canister characterized with a similar structure. If some changes are introduced to the canister designs, appropriate adjustments should be introduced to the experimental setup developed to investigate bentonite buffer thermal evolution (Figure 7).

The experiment is to be performed in a separate well with its location being extremely remote from other research excavations. It involves a mockup metal HLW canister - a heater and a framing material made of a selected metal fitted inside a system of compacted bentonite rings. To reduce the experiment time, two heaters and two systems of bentonite rings of different composition (from different deposits), as well as potential alternative buffer materials are to be engaged. A gap between the two heaters not being subject to heating will be provided: it could be used to install materials intended for RW class 2 disposal - buffer materials, concrete, etc. in keeping with the developed repository designs. Heating temperature should be specified based on the calculated one considering the heat output from HLW canisters provided for by the repository designs (a temperature of $130-150^{\circ} \mathrm{C}$ was adopted under similar experiments conducted in Switzerland and Sweden). Water will be supplied by pumping equipment.

Ring blocks of buffer material are placed around the mockup canister. To obtain most reliable results, blocks of the same composition are installed in 3-5-fold repetition. Reference materials can be placed with fewer repetitions, the most promising materials - with more repetitions. Several repetitions may involve materials of various EBS components proposed for tunnel backfilling purposes: concrete, thixotropic slip, bentonite pellets and, possibly, other promising materials.

The experiment is expected to last $5-7$ years with the upper heater and the blocks surrounding it expected to be removed after 3 years already, enabling to obtain preliminary results until project completion. The gaps between the walls of the well and the blocks will be backfilled with sand. Ground or model water will be injected into this gap being quickly distributed along the sandy layer ensuring uniform bentonite swelling.

To ensure optimal properties (swelling pressure, shear resistance, etc.), the type of bentonite buffer and alternative materials, property indicators and compaction parameters will be specified at the preliminary stage of the laboratory research. Available international experience and preliminary studies on the compaction of Russian bentonites show that compaction of bentonites with the desired and required properties cannot be achieved given the technical specification for compaction laid down in the engineering documentation (moisture content of $6 \%$ ), thus, requiring some additional computational and experimental studies.

Technical specifications for compaction (moisture content, fractional composition, etc.) should be developed for each potential bentonite buffer material, since their provisions depend on the composition and structure of the initial clay raw material.

Real time implementation of the full-scale experiment will provide indicators of evolving bentonite temperature and moisture content. Temperature 


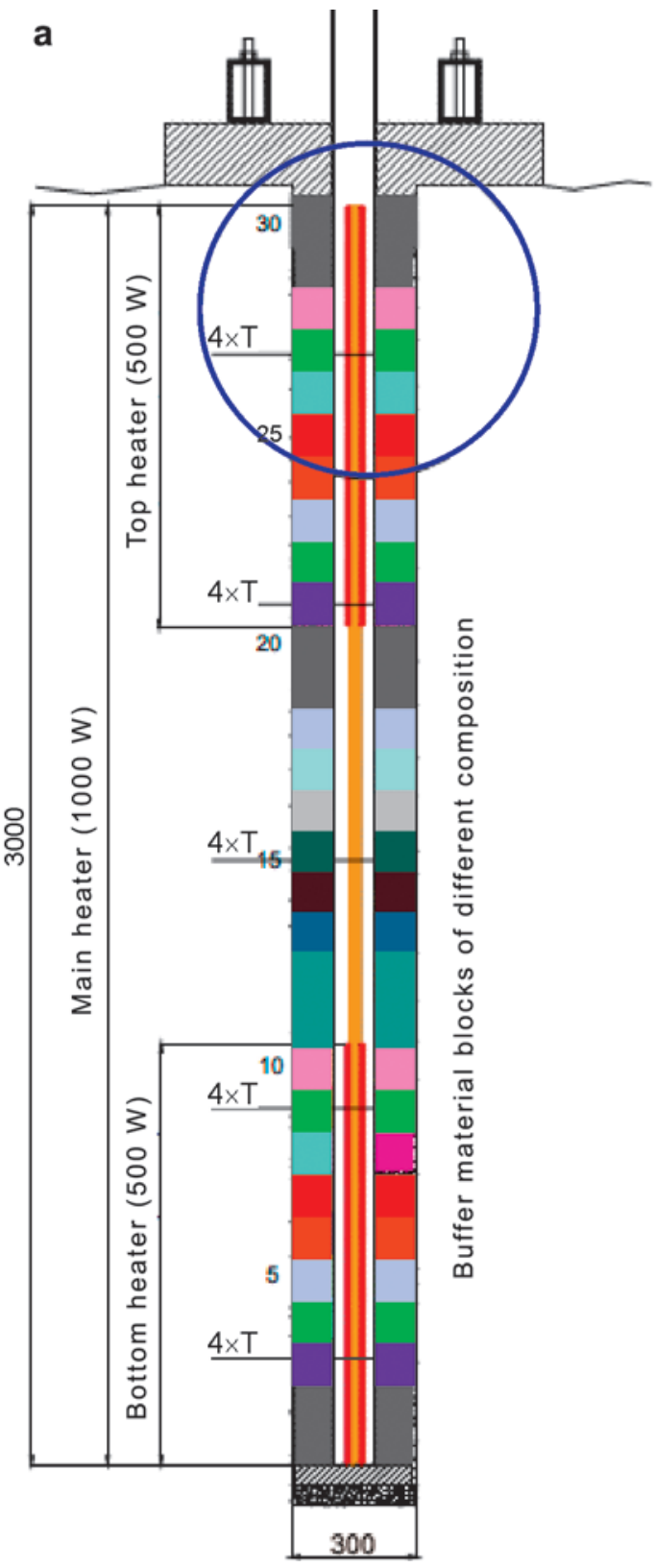

b
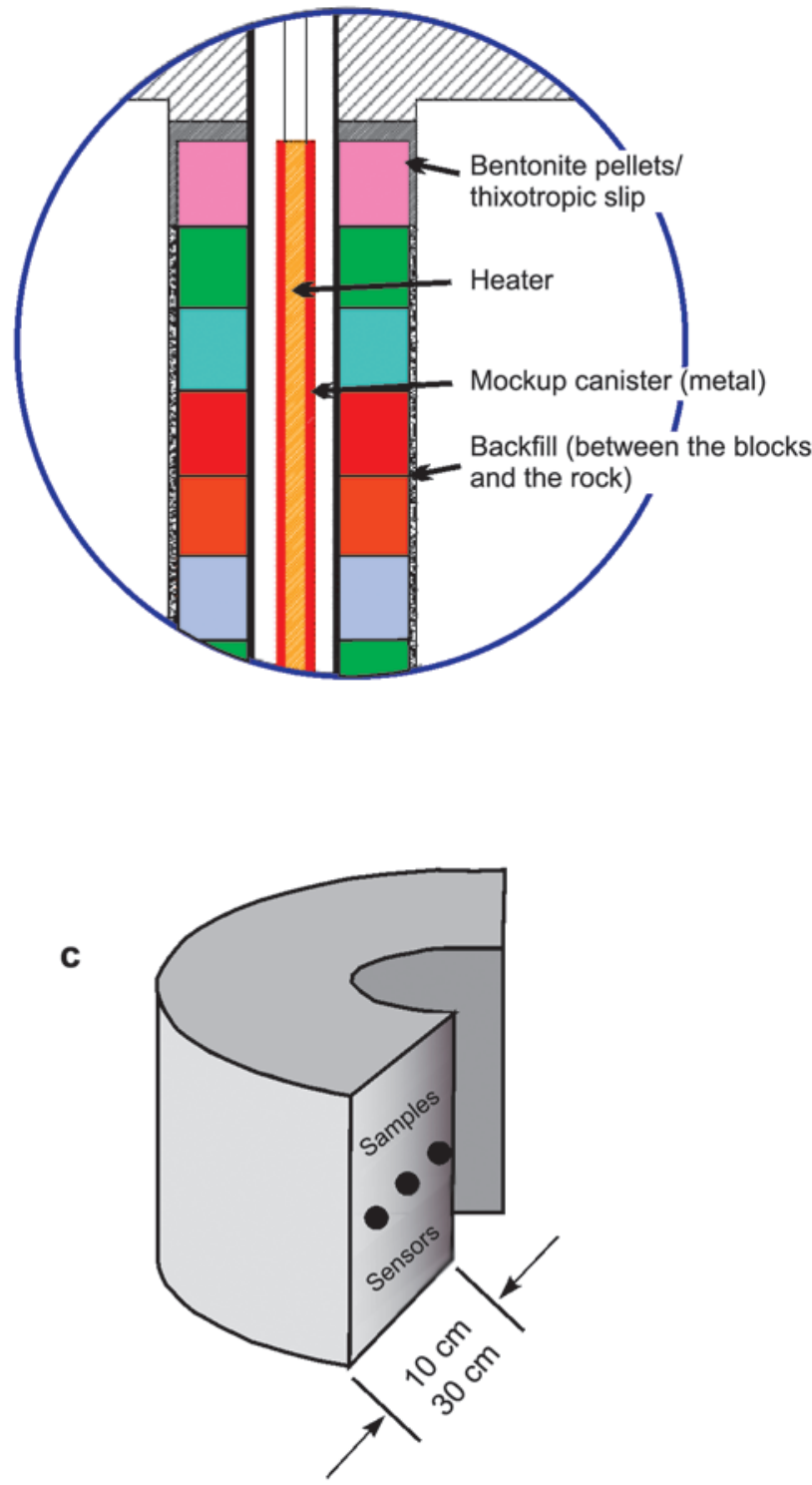

Figure 7. Layout of a full-scale experiment under the ThermoEvolution project:

$a$ - layout of blocks and heater in the well, $b$ - enlarged fragment accounting for mutual arrangement of EBS materials and the heater, $\mathrm{C}$ - assumed layout of sensors inside the blocks of compacted bentonite material

and moisture content sensors will be installed at different distances from the heating element, as shown in Figure 7a, the specific layout will depend on the thickness of the bentonite buffer. Experiment time will be shortened by reducing the thickness of the bentonite rings. Ring thickness of $12 \mathrm{~cm}$ is currently considered under the Russian disposal concept, whereas the international practice evidences that in this case appropriate safety level will not be attained and the ring fabrication process will be too complex given the manufacturing tolerance of $5 \mathrm{~cm}$. Two mock-ups with 10 and $30 \mathrm{~cm}$ thick compacted bentonite rings are planned to be tested. Under all existing repository concepts suggesting RW disposal in crystalline rocks, the thickness of the bentonite buffer is assumed to fall within the range of $35-40 \mathrm{~cm}$ with some designs providing for a $60 \mathrm{~cm}$ thick buffer.

\section{Studying the evolution of tunnel backfill properties}

Engineering repository documentation currently suggests that the tunnels will be backfilled with a cement-based material after the wells with HLW are sealed and the packages with RW class 2 are installed. Alternative tunnel and shaft backfilling options suggest the potential use of clay compacted material or clay-based mixtures. In this case, the tunnels will be backfilled with pre-compacted bentonite blocks (under Swedish disposal concept) or compacted pellets (under the designs adopted in Finland) following HLW canisters emplacement 
into vertical boreholes. Remaining gaps between the blocks and the borehole walls will be backfilled with bentonite granules or pellets. An experiment is proposed to study the processes resulting from the interaction of swellable tunnel backfilling materials and concrete plugs to evaluate the applicability of this method along with the evaluation of tunnel backfill material evolution and the elaboration of relevant engineering solutions.

The experiment will be also focused on the swelling of tunnel backfill material - blocks made of compacted bentonite/alternative materials, mixtures of bentonite sand, etc., as well as on the effects produced by backfill materials on the concrete and other repository materials, the impact of pore water on backfill tunnel material interactions and etc.

\section{Experiment on gas generation} and migration through EBS materials

Another type of experiments suggests the evaluation of gas generation, its migration through EBS materials, primarily high-density bentonites. Gas releases, for example, due to steel canister corrosion, microbiological impacts, destruction of calcite contained in bentonite, as well as bedrock heating in the vicinity of HLW canisters, can potentially affect the buffer quality. Furthermore, gas penetration channels may be developed within the buffer. If the gas is not able to pass through the buffer, the pressure will increase potentially causing mechanical damage to other barrier elements. In addition, the gas can dry the bentonite buffer. Findings of this experiment will help to identify potential factors associated with gas generation and its impact on possible structural montmorillonite transformations.

Experiment layout is similar to the ThermoEvolution one. The only difference is that for each particular buffer material an individual layout should be arranged. Heaters are placed inside the buffer samples. The experiments would last some 5-10 years. Gas and temperature sensors are fitted within the blocks and the surrounding rock. During the experiment, gas samples will be collected continuously with their composition being analyzed.

To evaluate the rate of gas migration and discontinuities in the bentonite buffer, a separate experiment can be arranged: the gas will be pumped into a mockup container using pumping equipment.

Full-scale experiments are mainly focused on:

- metal container corrosion driven impacts of gas on bentonite buffer properties;

- formation of possible gas migration pathways in bentonite buffer;

- risks of damage in case of too low gas permeability of the buffer;
- consequences of potential bentonite buffer dehydration prompted by gas generation;

- impacts of gas generation on the properties of alternative buffer materials, involving the study of relevant mechanisms and their comparison.

\section{Laboratory experiments focused on EBS material interactions in the repository}

Laboratory experiments are seen as an important stage of full-scale URL research. Studies focused on the interactions occurring at the boundaries of barrier materials are planned. Samples of canister materials (steel, copper, etc.) and various clay materials - bentonites and alternative composite mixtures (Figure 8) were chosen to study the interactions. The experiments are supposed to be carried out under aerobic and anaerobic conditions to evaluate the effect of microbial activity on the rate and nature of EBS material corrosion.

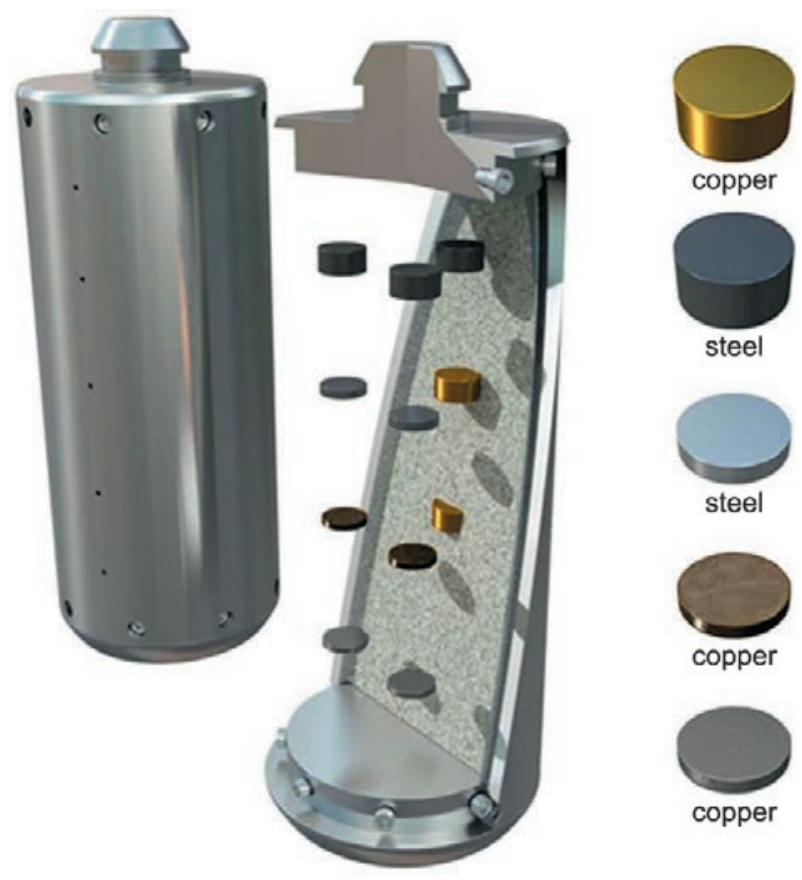

Figure 8. Layout of laboratory experiments to study the interactions at the interface between bentonite and HLW/SNF canister metal material

The experiment will investigate the transformations occurring at the boundary of barrier materials: interactions between bentonite and metal canister (using different materials), interactions between bentonite and concrete, the impacts produced by pore water, temperature and microbial activity on the rate and nature of transformations in the contact locations of the materials.

Evaluation of swelling pressure, water conductivity and diffusion coefficients

Swelling pressure indicators, water conductivity, diffusion and gas permeability coefficients are 
considered as key characteristics affecting the containment properties of the bentonite barrier.

Swelling pressure of compacted bentonite samples is measured in a rigid chamber of a known volume, the internal dimensions of which correspond to the size of the sample. The pressure developed in the chamber due to sample wetting is measured using a strain gauge.

Measurements of bentonite and bentonite-based material permeabilities appear to be rather a difficult task since a visco-plastic filtration mode can evolve in the sample pores. Therefore, water conductivity coefficients of bentonite-based EBS materials can be correctly measured under laboratory conditions only if real hydraulic gradients being considered common for the selected repository site are simulated. Such a setup involves large time and labor costs, since one experiment can last several months. Filtration experiments involving largescale hydraulic gradients can be considered as an option of a worst-case scenario. The method used to identify water conductivity coefficients is based directly on solution seepage through a sample followed by relevant measurements of the liquid volume filtered over time.

The permeability experiment can be carried out using a triaxial compression device. In this case, comprehensive isotropic compression of the bentonite sample evolves which is required to simulate the pressure developed within the rock mass and prevent near-wall filtration. Since such research involves long-lasting experiments and correct results can be obtained only based on a series of samples, the use of such a device seems to be quite unpromising.

Water conductivity coefficient can be also identified indirectly using data from a consolidation experiment. The theory of filtration consolidation suggests that the dynamics of soil deformation under load is related to the outflow rate of the pore solution given complete water saturation [42].

Thus, to assess the key properties of bentonite buffers over a foreseeable time period, as well as the opportunities for obtaining a representative number of experiments, various research groups usually specifically develop such equipment on their own [43-49]. Experimental installations are based on similar key points, but differ in terms of the implemented structural and engineering solutions.

Basically, an installation designed to measure swelling pressure indicators, water conductivity and diffusion coefficients features a cylindrical body with one sidewall being used as a fixed foundation and penetrated by holes for solution injection/removal and a forcer at the upper sidewall (Figure 9). The studied samples have a diameter of $30 \mathrm{~mm}$ with

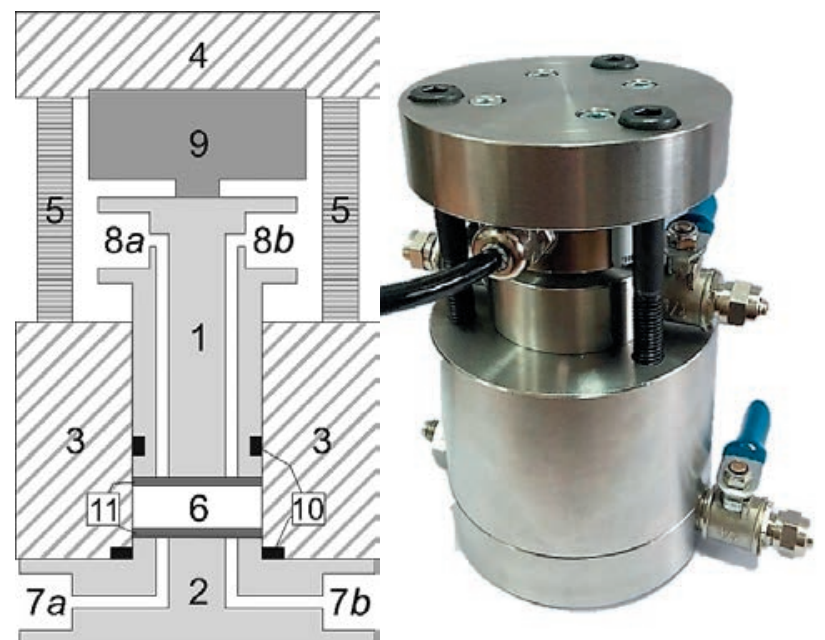

Figure 9. Layout of a pilot installation for compacted bentonite sample manufacturing and swelling pressure, water conductivity and diffusion coefficient measurements:

1 - forcer, 2 - foundation, 3 - body, 4 - thrust plate, 5 - bolts, 6 - sample chamber, $7 a, b$ - lower inlet and outlet, $8 a, b$ - upper inlet and outlet, 9 - strain gauge, 10 - sealing rings, 11 - porous metal filter

their thickness ranging from 5 to $15 \mathrm{~mm}$ suggesting an increment of $5 \mathrm{~mm}$.

Swelling pressure is measured via uniform soaking of a test sample from the lower side-wall inside a limited volume chamber, which provides more correct data on the swelling pressure indicators. Water conductivity coefficients are measured after the completion of the swelling pressure experiment. Following the completion of the filtration experiment, diffusion coefficients of neutral and absorbed elements, active porosities and sorption parameters can be evaluated using different combinations of diffusion experiment layouts described in literature.

Figures 10 and 11 present the dependences of filtration coefficients and swelling pressures depending on the matrix density of the compacted bentonites from the 10th Khutor deposit. Filtration coefficients at a matrix density range of $1.46-1.82 \mathrm{~g} / \mathrm{cm}^{3}$ vary from $5.34 \cdot 10^{-13}$ to $2.06 \cdot 10^{-14} \mathrm{~m} / \mathrm{s}$. The obtained data on the filtration coefficients are characterized with an exponential approximation of the following type $\ln (y)=-0.00903 x-14.778$ with a determination coefficient $R^{2}=0.93$. Assuming dry density of the compacted samples of $1.44-1.82 \mathrm{~g} / \mathrm{cm}^{3}$, the swelling pressures ranged from 0.52 to $9.39 \mathrm{MPa}$ and could be finely described by an exponential dependence of the following type: $\ln (y)=0.0064 x-9.403$ with a determination coefficient $R^{2}=0.95$.

These preliminary experiments have demonstrated that in the studied density range, such characteristics of bentonites from the 10th Khutor deposit as water permeability and swelling pressure upon 


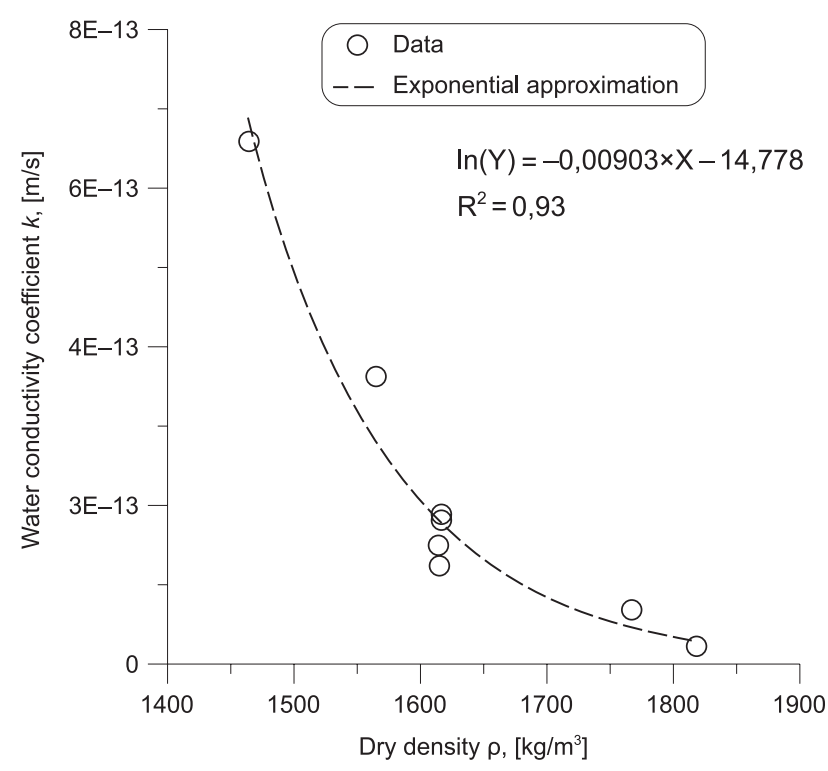

Figure 10. Dependence of water conductivity coefficients on the matrix density of compacted bentonite samples from the 10th Khutor deposit (based on the experiments performed by the geological faculty of the Moscow State University named after M.V.Lomonosov). Dashed line shows the approximation result

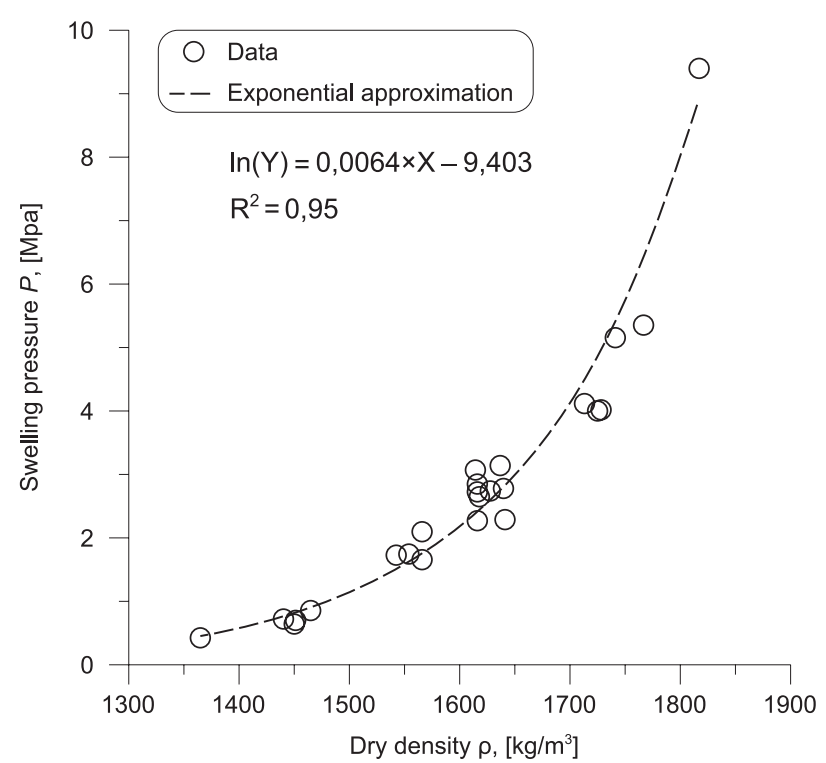

Figure 11. Dependence of swelling pressures on the matrix density of compacted bentonite samples from the 10th Khutor deposit (based on the experiments performed by the geological faculty of the Moscow State University named after M.V.Lomonosov). Dashed line shows the approximation result

their contact with distilled water primarily depended on the compacted sample matrix density. It was also shown that in case of smectite content of about $70 \%$, its ion-exchange complex composition did not produce any significant impact and could be balanced by adjusting the density [7].
Laboratory experiments focused on gas generation and migration through EBS materials

Intense gas generation can cause breaches in the bentonite buffer [50]. Laboratory experiments will enable a more advance design of the full-scale experiments described above.

Laboratory experiments focused on the potential impacts of gas migration on the compacted bentonite properties will involve the above-described or similar installation and will be performed under aerobic and anaerobic conditions.

To investigate gas generation under repository conditions, gas generation driven by thermal decomposition of calcite contained in bentonites and constituting to the material filling the cracks available in the crystalline rock mass should be studied. Similar activities involving core samples and selected bentonite materials will help to evaluate the gas generation nature and rates under conditions being similar to the repository ones.

Desorption of $\mathrm{CO}_{2}$ previously absorbed by clay minerals is considered as an important issue associated with gas generation evaluation. Studies show that at a temperature of $45-50{ }^{\circ} \mathrm{C}$ and a pressure of less than $20 \mathrm{MPa}$, clay minerals can adsorb substances on the particle surface and inside the interlayer space at rate of up to $1 \mathrm{mmol} / \mathrm{g} \mathrm{CO}_{2}$ (corresponding to $10 \%$ of the $\mathrm{CaCO}_{3}$ mass in clay) [51]. Gas desorption occurs in a staged manner being caused by dehydration $\left(70-200^{\circ} \mathrm{C}\right)$ and dehydroxylation $\left(550-650^{\circ} \mathrm{C}\right)$. It was shown $[39,52]$ that at temperatures of up to $100^{\circ} \mathrm{C}$ the amount of desorbed $\mathrm{CO}_{2}$ amounts to $23 \%$ with similar values amounting to $42 \%$ within a temperature range of $140-200^{\circ} \mathrm{C} . \mathrm{CO}_{2}$ desorption from the surface of bentonite particles is mainly affected by its density and structural features of montmorillonite [52], thus, demonstrating the need of implementing relevant experiments on $\mathrm{CO}_{2}$ sorption and desorption. Experiments focused on the influence of microbial activity and discussed in detail in [35] are considered as a particularly important component in the assessment of gas generation processes.

\section{Conclusion}

Numerous researches have shown that bentonite can be considered as almost an ideal containment material of natural occurrence and therefore was selected as an EBS component in all concepts providing for repository siting in crystalline bedrock.

It was found that the content of montmorillonite should be high enough to maintain the required swelling pressure, to ensure sufficiently low permeability and the required strength. At the same time the content of adverse impurity components (pyrite, calcite, organic matter, etc.) should be kept as 
low as possible. It should be noted that to date, the scientific community has not reached any consensus on the potential negative impact of impurities in the entire range of operating conditions and detailed studies are required to be performed under a setup being similar to the repository one.

Characteristics and density of the selected reference bentonite may vary under different national disposal concepts, but the density of dry material (matrix density) usually falls in the range of $1.45-1.75 \mathrm{~g} / \mathrm{cm}^{3}$ given a homogenous buffer being installed into HLW/SNF disposal cell.

Compacted (compressed) bentonite elements should be installed around HLW containers ensuring the required EBS containment properties in the near- and long-term perspective.

Clay buffer material containment properties are characterized by the following key indicators: swelling pressure, heat resistance, water conductivity and diffusion coefficients, structural resistance to changes in external conditions. Numerous studies have shown that the sorption capacity of bentonites is sufficiently high to ensure the fixation of various radionuclides and heavy metals contained in the waste.

To demonstrate the near-term and long-term disposal safety, experiments focused on the behavior of EBS materials shall be implemented both under full-scale and laboratory conditions being to the extent possible similar to the actual conditions of repository operation.

The experiments will help to provide the required knowledge on the processes occurring in the EBS materials and to simulate the near-term and longterm evolution of the disposal system.

\section{Acknowledgments}

The authors are grateful to M. S. Chernov, Senior Researcher at the Department of Engineering and Ecological Geology, Geological Faculty, Moscow State University Lomonosov for his help in conducting microstructural studies, B. V. Pokidko, Associate Professor, Senior Researcher at the Department of Colloid Chemistry, Faculty of Natural Sciences, Lomonosov Moscow State University of Fine Chemical Technologies for his assistance in the study of the sorption properties of bentonites. The work was supported by the Russian Science Foundation under the project № 16-17-10270.

\section{References}

1. Sellin P., Leupin O. X. The use of clay as an engineered barrier in radioactive-waste management a review. Clay and Clay Minerals, 2013, vol. 61, no. 6, pp. 477-498.
2. Tsebakovskaya N. S., Utkin S. S., Kapyrin I. V. et al. Obzor zarubezhnyh praktik zahoroneniya OYAT i RAO [Overview of foreign practices of SNF and RW disposal]. Edited by Linge I. I., Polyakov Yu. D. Moscow, Komtekhprint Publ., 2015. 208 p.

3. Dixon D., Sandén T., Jonsson E., Hansen J. Backfilling of deposition tunnels: Use of bentonite pellets. SKB P-11-44. 2011. 46 p. URL: http://www.skb.com/ publication/2308782/P-11-44.pdf.

4. Technical Report, SKB 2010. TR-10-15. Design, production and initial state of the buffer. Svensk Kärnbränslehantering AB December 2010, 89 p.

5. Technical Rreport, SKB 2009. TR-09-52. Assessment of backfill design for KBS-3V repository. Svensk Kärnbränslehantering AB October 2009, 125 p.

6. Fries T., Claudel A., Weber H., Johnson L., Leupin O. The Swiss concept for the disposal of spent fuel and vitrified HLW. Intern. Conf. Underground Disposal Unit Design \& Emplacement Processes for a Deep Geological Repository. 16-18 June 2008. Prague. URL: http://library.sinap.ac.cn/db/fangshexing201103// 41025019.pdf.

7. Kaufhold S., Dohrmann R. Distinguishing between more and less suitable bentonites for storage of high-level radioactive waste. Clay Minerals, 2016, no. 51 (2), pp. 289-302.

8. Birgersson M., Hedström M., Karnland O., Sjöland A. Bentonite buffer: Macroscopic performance from nanoscale properties. Geological Repository Systems for Safe Disposal of Spent Nuclear Fuels and Radioactive Waste (Second Edition). 2017. Pp. 319-364. 9. Dorofeev A. N., Bolshov L. A., Linge I. I., Utkin S. S., Saveleva E. A. Strategicheskij master-plan issledovanij $\mathrm{v}$ obosnovanie bezopasnosti sooruzheniya, ekspluatacii i zakrytiya punkta glubinnogo zahoroneniya radioaktivnyh othodov [Strategic Master Plan for R\&D Demonstrating the Safety of Construction, Operation and Closure of a Deep Geological Disposal Facility for Radioactive Waste]. $R a-$ dioaktivnye othody - Radioactive Waste, 2017, no. 1, pp. 32-41.

10. Karnland O., Olsson S., Nilsson U. Mineralogy and sealing properties of various bentonites and smectite-rich clay materials. Technical Report TR 0630. Svensk Kärnbränslehantering AB, Sweden. 2006. 112 p. URL: http://www.skb.se/upload/publications/ pdf/TR-06-30.pdf.

11. Karnland O., Olsson S., Dueck A., Birgersson M., Nilsson U., Hernan-Håkansson T., Pedersen K., Nilsson S., Eriksen T. E., Rosborg B. Long term test of buffer material at the Äspö Hard Rock Laboratory, LOT project. Final report on the A2 test parcel, Technical Report TR-09-29. 2009. 297 p.

12. Wersin P. LOT A2 test parcel. Compilation of copper data in the LOT A2 test parcel. Technical Report TR-13-17. 2013. 28 p. 
13. Geological Disposal: A review of the development of bentonite barriers in the KBS-3V disposal concept. NDA Technical Note 21665941. 2014. 84 p.

14. Ahonen L., Korkeakoski P., Tiljander M., Kivikoski H., Laaksonen R. Quality Assurance of the Bentonite Material. Posiva Working Report 2008-33. Eurajoki, Finland. 2008. 126 c. URL: http://www.posiva.fi/ files/526/WR_2008-33_web.pdf.

15. Krupskaya V. V., Biryukov D. V., Belousov P. E., Lekhov V. A., Romanchuk A. Yu., Kalmykov S. N. Primenenie prirodnyh glinistyh materialov dlya povysheniya urovnya yadernoj i radiacionnoj bezopasnosti ob"ektov yadernogo naslediya [The use of natural clay materials to increase the nuclear and radiation safety level of nuclear legacy facilities]. Radioaktivnye othody - Radioactive Waste, 2018, no. 2 (3), pp. 30-43.

16. Belousov P. E. Sravnitel'naya harakteristika mestorozhdenij vysokokachestvennyh bentonitov Rossii i nekotoryh zarubezhnyh stran [Comparative characteristic of high-quality bentonite deposits of Russia and some foreign countries]. Vestnik Rossijskogo universiteta druzhby narodov. Seriya: Inzhenernye issledovaniya - RUDN Journal of Engineering researches, 2013, no. 2, pp. 55-61.

17. Belousov P. E., Krupskaya V. V., Zakusin S. V., Zhigarev V. V. Bentonitovye gliny mestorozhdeniya 10-j Hutor (respublika Hakasiya): osobennosti genezisa, sostava i adsorbcionnyh svojstv [Bentonite clays from 10th Khutor deposite: features of genesis, composition and adsorption properties]. Vestnik Rossijskogo universiteta druzhby narodov. Seriya: Inzhenernye issledovaniya - RUDN Journal of Engineering researches, 2017, vol. 18, no. 1, pp. 135-143. 18. Dohrmann R., Genske D., Karnland O., Kaufhold S., Kiviranta L., Olsson S., Plötze M., Sandén T., Sellin P., Svensson D., Valter M. Interlaboratory CEC and exchangeable cation study of bentonite buffer materials: I. Cu(II)-triethylenetetramine method. Clays and Clay Minerals, 2012, vol. 60, no. 2, pp. 162-175.

19. Lorenz P., Meier L., Kahr G. Determination of the cation exchange capacity (CEC) of clays minerals using the complexes of copper (II) ion with triethylenetetramine and tetraethylenepentamine. Clays and Clay Minerals, 1999, vol. 47, no. 3, pp. 386-388.

20. GOST 22733-2016. Grunty. Metod laboratornogo opredeleniya maksimal'noj plotnosti [State Standard 22733-2016. Soils. Laboratory method for determining of maximum density]. Moscow, Standartinform Publ., 2016. 12 p.

21. Eriksson P. Compaction properties of bentonite clay. Technical Report TR-16-16. Svensk Kärnbränslehantering AB, Sweden. 2017. 41 p. URL: http:// www.skb.com/publication/2488183/TR-16-16.pdf.

22. Osipov V. I., Sokolov V. N. Gliny i ih svojstva. Sostav, stroenie $i$ formirovanie svojstv [Clays and their properties. Composition, structure and formation of properties]. Moscow, GEOS Publ., 2013. 576 p.

23. Holmboe M., Wold S., Jonsson M. Porosity investigation of compacted bentonite using XRD profile modeling. Journal of Contaminant Hydrology, 2012, vol. 128, no. 1-4, pp. 19-32.

24. Van Geet M., Volckaert G., Roels S. The use of microfocus X-ray computed tomography in characterising the hydration of a clay pellet/powder mixture. Applied Clay Sciences, 2005, no. 29, pp. 73-87.

25. Wang Q., Tang A. M., Cui Y.-J., Delage P., Gatmiri B. Experimental study on the swelling behavior of bentonite/claystone mixture. Engineering Geology, 2012, no. 124, pp. 59-66.

26. Karnland O. Bentonite swelling pressure in strong NaCI solutions Correlation of model calculations to experimentally determined data. POSIVA report 98-01. 1998. 35 p. URL: http://www.posiva.fi/files/2666/ POSIVA-98-01_web.pdf.

27. Dixon D. A., Gray M. N., Graham J. Swelling and hydraulic properties of bentonites from Japan, Canada and USA. Proc. of the 2nd International Congress on Environmental Geotechnics, Osaka, Japan, 1996. Pp. 5-8.

28. Pashley R. M., Israelachvili J. N. Molecular layering of water in thin films between mica surfaces and its relation to hydration forces. Journal of Colloid and Interface Science, 1984, vol. 101, no. 2, pp. 511-523. 29. Hökmark H., Lönnqvist M., Fälth B. THM-issues in repository rock. Thermal, mechanical, thermo-mechanical and hydromechanical evolution of the rock at the Forsmark and Laxemar sites. SKB TR-10-23. Svensk Kärnbränslehantering AB. Stockholm. 2010. 268 p. URL: https://inis.iaea.org/collection/NCLCollectionStore/_Public/41/103/41103172.pdf?r=1 \&r=1. 30. Börgesson L., Fredrikson A., Johannesson L.-E. Heat conductivity of buffer materials. SKB Technical Report TR 94-29. Svensk Kärnbränslehantering AB, Sweden. 1994. 63 p. URL: http://www.skb.com/publication/11249/TR94-29.pdf.

31. Plötze M., Valter M. Bentonite as barrier material thermal conductivity of compacted bentonite. NAGRA Arbeitsbericht NAB 11-16 National Cooperative for the Disposal of Radioactive Waste, Switzerland. 2011. 32. Huertas F., Fuentes-Cantilliana J. L., Rivas F., Linares J., Farina P., Jockwer N., Kickmaier W., Martinet M. A., Samper J., Alonso E., Elorza F. S. Full scale engineered barriers experiment for a high level radioactive waste in crystalline host rock (FEBEX project): final report. EUR 19147 EN. European Commission, Brussels. 2000.

33. Gu B. X., Wang L. M., Minc L. D., Ewing R. C. Temperature effects on the radiation stability and ion exchange capacity of smectites. Journal of Nuclear Materials, 2001, no. 297, pp. 345-354.

34. Pusch R., Karnland O., Lajudie A., Decarreau A. MX 80 clay exposed to high temperatures and gamma 
radiation. SKB TR 93-03. Svensk Kärnbränslehantering $A B$, Sweden. 1993. 54 p. URL: http://www.skb. com/publication/8678/TR93-03webb.pdf.

35. Safonov A. V., Boldyrev K. A. Issledovanie biogennyh processovv PIL PGZRO v Nizhnekanskom massive [URL in the Nizhnekanskiy Massif: Studying Biogenic Processes under HLW Disposal Project]. Radioaktivnye othody - Radioactive Waste, 2019, no. 2 (7), pp. 92100. DOI: 10.25283/2587-9707-2019-2-92-100.

36. Huang W., Longo J., Pevear D. An experimentally derived kinetic model for smectite-to-illite conversion and its use as a geothermometer. Clays and Clay Minerals, 1993, no. 41, pp. 162-177.

37. Pytte A., Reynolds R. The thermal transformation of smectite to Illite. Chapter 8. In: Thermal History of Sedimentary Basins. Hrsg: Naer M. C., McCulloh T. H., 133-140, Springer: New York, USA, 1989.

38. Zakusin S.V., Krupskaya V. V., Dorzhieva O. V., Zhuhlistov A. P., Tyupina E. A. Modification of the adsorption properties of montmorillonite by the thermochemical treatment. Sorbtsionnye i Khromatograficheskie Protsessy - Sorption and chromatography processes, 2015, vol. 15, no. 6, pp. 874-883. (In English). 39. Krupskaya V., Novikova L., Tyupina E., Belousov P., Dorzhieva O., Zakusin S., Kim K., Roessner F., Badetti E., Brunelli A., Belchinskaya L. The influence of acid modification on the structure of montmorillonites and surface properties of bentonites. Applied Clay Science, 2019, vol. 172. Pp. 1-10.

40. Drits V. A., McCarty D. K., Zviagina B. B. Crystalchemical factors responsible for the distribution of octahedral cations over trans- and cis-sites in dioctahedral 2:1 layer silicates. Clays and Clay Minerals, 2006, vol. 54, no. 2, pp. 131-152.

41. Drits V. A., Besson G., Muller F. An improved model for structural transformations of heat-treated aluminous dioctahedral 2:1 layer silicates. Clays and Clay Minerals, 1995, vol. 43, no. 6, pp. 718-731.

42. Necib S., Diomidis N., Keech P., Nakayama M. Corrosion of carbon steel in clay environments relevant to radioactive waste geological disposals, Mont Terri rock laboratory (Switzerland). Swiss Journal of Geosciences, 2017, vol. 110, pp. 329-342.

43. GOST 25584-2016. Grunty. Metody laboratornogo opredeleniya koefficienta fil'tracii [State Standard 25584-2016]. Soils. Laboratory methods for determination of coefficient of hydraulic conductivity]. Moscow, Standartinform Publ., 2016. 20 p.
44. Cavé L., Al T., Xiang Y., Vilks P. A technique for estimating one-dimensional diffusion coefficients in low-permeability sedimentary rock using X-ray radiography: Comparison with through-diffusion measurements. Journal of Contaminant Hydrology, 2009, vol. 103, no. 1-2, pp. 1-12.

45. Cho W. J., Oscarson D. W., Hahn P. S. The measurement of apparent diffusion coefficients in compacted clays: an assessment of methods. Applied Clay Science, 1993, vol. 8, no. 4, pp. 283-294.

46. Hume H. B., Banthia N. Procedures and apparatus for measuring diffusion and distribution coefficients in compacted clays. Atomic Energy Canada Limited, AECL, 1993, no. 10981, pp. 1-40.

47. Loon L. R. Van, Soler J. M., Bradbury M. H. Diffusion of HTO, 36Cl- and 125I- in Opalinus Clay samples from Mont Terri: Effect of confining pressure. Journal of Contaminant Hydrology, 2003, vol. 61, no. $1-4$, pp. $73-83$.

48. Wang B.-T., Lee C.-P., Wu M.-C., Tsai T.-L., Tsai S.-C., Hsu K.-C. Novel method for analyzing transport parameters in through-diffusion tests. Journal of Environmental Radioactivity, 2019, vol. 196, pp. 125-132.

49. Zhu C.-M., Ye W.-M., Chen Y.-G., Chen B., Cui Y.-J. Influence of salt solutions on the swelling pressure and hydraulic conductivity of compacted GMZ01 bentonite. Engineering Geology, 2013, vol. 166, pp. 74-80. 50. Johannesson L.-E.Manufacturing ofbuffer and filling components for the Multi Purpose Test. P-14-07. Svensk Kärnbränslehantering $\mathrm{AB}$, Sweden. 2014. 29 p. URL: http://www.skb.com/publication/2478195/P-14-07.pdf. 51. Namiki K., Asano H., Takahashi S., Shimura T., Hirota K. Laboratory gas injection tests of compacted bentonite buffer material for TRU waste disposal. Geological Society. London. Special Publications. 2014, v. 400, pp. 521-529. doi.org/10.1144/SP400.27.

52. Busch A., Bertier P., Gensterblum Y., Rother G., Spiers C. J., Zhang M., Wentinck H. M. On sorption and swelling of $\mathrm{CO}_{2}$ in clays on sorption and swelling of $\mathrm{CO}_{2}$ in clays. Geomechanics and Geophysics for Geo-Energy and Geo-Resources, 2016, vol. 2, no. 2, pp. $111-130$.

53. Azzouz A., Nousir S., Platon N., Ghomai K., Shiao T. C., Hersant G., Bergeron J. Y., Roy R. Truly reversible capture of $\mathrm{CO}_{2}$ by montmorillonite intercalated with soya oil-derived polyglycerols. International Journal of Greenhouse Gas Control, 2013, vol. 17, pp. 140-147.

\section{Information about the authors}

Krupskaya Victoria Valer'yevna, Candidate of Geologo-Mineralogical Sciences, Senior Researcher, Institute of Ore Deposits, Petrography, Mineralogy and Geochemistry of the Russian Academy of Sciences (35, Staromonetnyy per., Moscow, 119017, Russia); Senior Researcher, Nuclear Safety Institute of the Russian Academy of Sciences (52, Bolshaya Tulskaya st., Moscow, 115191, Russia), e-mail: krupskaya@ruclay.com. 
Zakusin Sergej Vyacheslavovich, Junior researcher, Institute of Ore Deposits, Petrography, Mineralogy and Geochemistry of the Russian Academy of Sciences (35, Staromonetnyy per., Moscow, 119017, Russia), e-mail: zakusinsergey@gmail.com.

Lekhov Vladimir Alekseyevich, Researcher, Lomonosov Moscow State University (1, Leninskiye gory, Moscow, 119991, Russia), e-mail: v.lekhov@gmail.com.

Dorzhieva Ol'ga Valer'evna, Junior researcher, Institute of Ore Deposits, Petrography, Mineralogy and Geochemistry of the Russian Academy of Sciences (35, Staromonetnyy per., Moscow, 119017, Russia), e-mail:dorzhievaov@gmail.com.

Belousov Petr Yevgen'yevich, Candidate of Geologo-Mineralogical Sciences, Senior Researcher, Institute of Ore Deposits, Petrography, Mineralogy and Geochemistry of the Russian Academy of Sciences (35, Staromonetnyy per., Moscow, 119017, Russia), e-mail: pitbl@mail.ru.

Tyupina Ekaterina Aleksandrovna, Candidate of Technical Sciences, Assistant Professor, D. Mendeleev University of Chemical Technology of Russia (9, Miusskaya pl., Moscow, 125047, Russia), e-mail: tk1972@mail.ru.

\section{Bibliographic description}

Krupskaya V.V., Zakusin S. V., Lekhov V. A., Dorzhieva O. V., Belousov P.E., Tyupina E. A. Buffer Properties of Bentonite Barrier Systems for Radioactive Waste Isolation in Geological Repository in the Nizhnekanskiy Massif. Radioactive Waste, 2020, no.1 (10), pp. 35-55.(In Russian). DOI: 10.25283/2587-9707-2020-1-35-55. 